\title{
EERSTETAALOORDRAG BY AANVANGSLEERDERS VAN ENGELS AS TWEEDE TAAL
}

\author{
Elza Hattingh en Cecile le Roux
}

\section{Inleiding'}

'n Tweedetaal (T2)-leerder, anders as ' $n$ eerstetaal (T1)-leerder, beskik reeds oor grammatikale kennis van ' $n$ taal. Die meerderheid T2-navorsers aanvaar dat die T1grammatika wel ' $n$ rol speel in T2-verwerwing. Daar bestaan egter meningsverskille oor die aard en omvang van die rol wat die T1-grammatika in T2-verwerwing speel. Een van die vrae wat gevra word, is wat presies vanaf die T.1-grammatika oorgedra word. Onlangse studies binne die raamwerk van die 'Government and Binding' model van die grammatika het interessante antwoorde op hierdie vraag opgelewer.

Navorsers soos Vainikka en Young-Scholten (1996: 33) beweer dat oordrag beperk is tot leksikale kategoriee, aangesien T2-leerders aanvanklik slegs verbale frases (VP) produseer. Funksionele kategorieë word nie vanaf die T1 oorgedra nie, maar word geleidelik verwert soos die T2-leerder se intertaal (IT) ontwikkel.

In teenstelling met Vainikka en Young-Scholten, beweer navorsers soos Schwartz en Sprouse (1996 : 46) dat funksionele kategorieè reeds vroeg in die IT-grammatika teenwoordig is en dat die T2-leerder se kennis van funksionele kategorieë oorgedra word vanaf die T1 (sien ook Gavruseva en Lardière 1996: 235; Lardière 1998: 1; Grondin en White 1993: 121; White 1989: 50). Die teenwoordigheid van funksionele kategories word weerspieel in woordorde en die voorkoms van kongruensiemorfologie.

In die studie waaroor in hierdie artikel verslag gedoen word, is die teenwoordigheid van die funksionele kategorie IP in die IT-grammatika van Afrikaanssprekende aanvangsleerders van Engels as T2 ondersoek. Om vas te stel of die funksionele kategorie IP voorkom in die vroee IT-grammatika van die T2-leerders, is ' $n$ ontleding gemaak van woordorde en die voorkoms van kongruensiemorfologie in uitings wat deur hierdie leerders geproduseer word. Daar is ook nagegaan of daar ' $n$ verband bestaan tussen blootstellingstyd aan die $T 2$ en die teenwoordigheid, al dan nie, van die funksionele kategorie IP in die IT-grammatika. 


\section{Teoretiese bespreking}

\subsection{Woordorde}

Daar is ' $n$ verskeidenheid van verskille in woordorde tussen Afrikaans en Engels. ' $n$ Paar van die verskille het te doen met die posisie van werkwoorde t.o.v. (i) negatiewe elemente - kyk (1) hieronder, (ii) sinsinisiële wh-vraagwoorde - kyk (2) hieronder, (iii) VP-inisiële bywoorde - kyk (3) hieronder, (iv) die subjek-NP in ja/neevraagsinne - kyk (4) hieronder, en (v) sinsinisiële bywoorde - kyk (5) hieronder. Die verskille word in (1) - (5) geillustreer.

(1) (a) Ek hou nie van slange nie.

(b) *like not snakes.

(c) Ido not like snakes.

(2) (a) Wat eet jy vir ontbyt?

(b) "What eat you for breakfast?

(c) What do you eat for breakfast?

(3) (a) Hy gaan dikwels kerk toe.

(b) He goes often to church.

(c) He often goes to church.

(4) (a) Het jy'n bal?

(b) "Have you a ball?

(c) Do you have a ball?

(5) (a) Môre speel ek met' $n$ bal.

(b) "Tomorrow play / with a ball.

(c) Tomorrow / play with a ball.

Afrikaans is, soos Duits en Nederlands, ' $n$ V2-taal, d.i. die finiete werkwoord staan altyd in hoofsinne in die tweede sinsposisie. In V2-tale beweeg die finiete werkwoord na die komplementeerderposisie (C) indien die posisie oop is. Die werkwoordbeweging vind plaas in hoofsinne maar nie in onderskikkende sinne nie (Cook 1996: 222). In stelsinne moet die spesifiseerder (Spec) van die komplementeerderfrase (CP) gevul wees as $C$ 'n finiete werkwoord bevat. Die subjek, ' $n$ objek of ' $n$ bywoord kan in hierdie posisie verskyn. ${ }^{2}$ ' $n$ Boomdiagram wat die struktuur van die sinne in (1) - (5) weergee, is in figuur 1 te sien. ${ }^{3}$ 


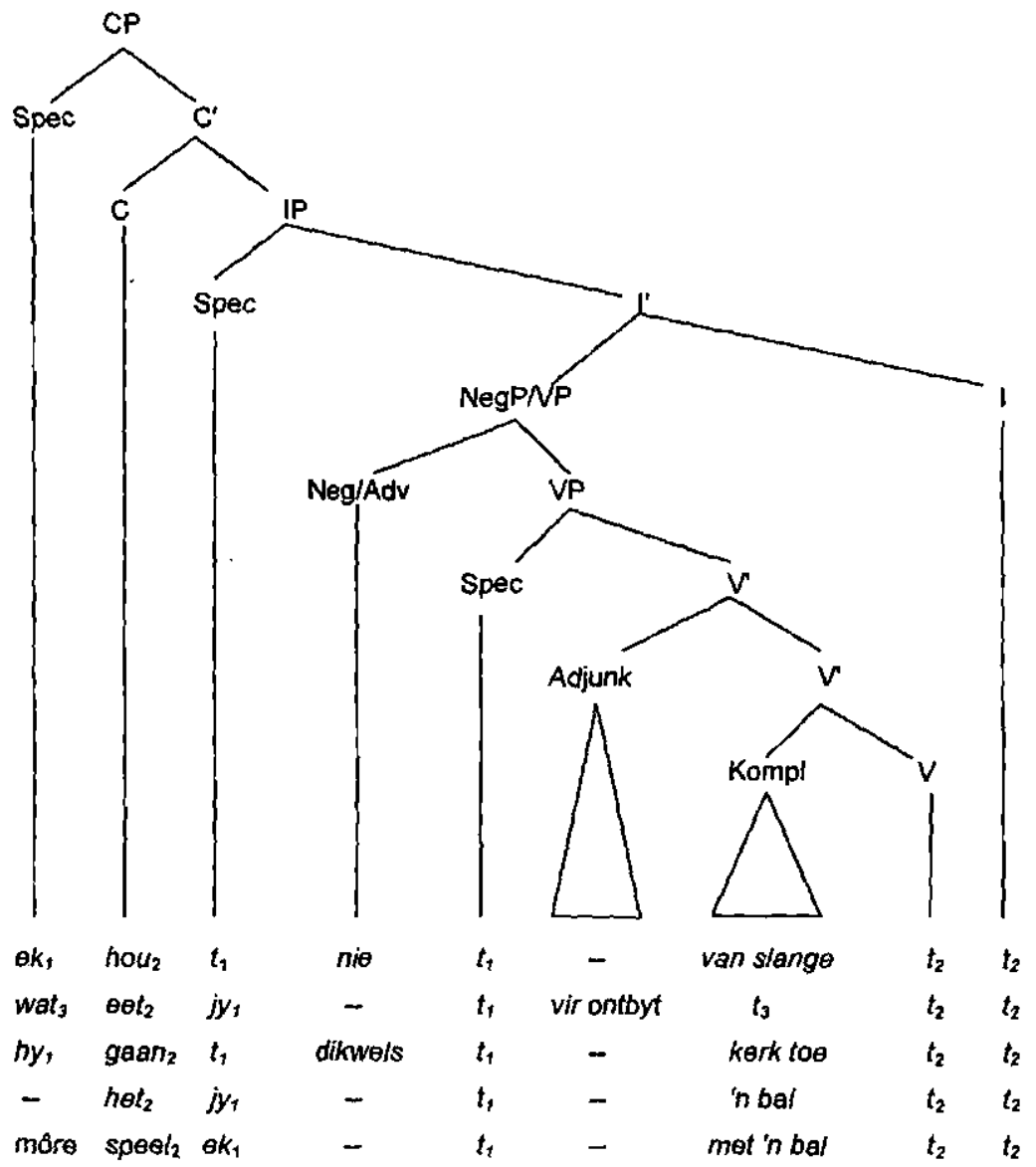

Flgurur 1
1. Negatiewe sin:
2. Wh-vraag:
Ek hou nie van slange nie.
3. VP-inisièle bywoord:
4. Ja/nee-vraagsin:
Wat $\theta \theta t j y$ vir ontbyt?
Hy gaan dikwels kerk toe.
5. Sinsinisiele bywoord:
Het jy ' $n$ bal?
Môre speel ek met 'n bal. 
In Afrikaans verhoog die werkwoord bo-oor die negatief sodat die negatief regs van die werkwoord verskyn, soos in (1a). In ja/nee-vraagsinne, anders as in stelsinne, verskyn die werkwoord links van die subjek, soos in (4a). Alhoewel die werkwoord verhoog na $C$, bly die [Spec,CP]-posisie leeg, anders as in stelsinne waar [Spec,CP] gevul moet wees indien $C$ 'n finiete werkwoord bevat. Die rede vir die lee [Spec,CP]-posisie in ja/nee-vraagsinne het waarskynlik te doen met die eis dat slegs ' $n$ vraagelement (whelement) in vraagsinne in [Spec,CP] kan verskyn (Radford 1997: par. 7.7). In ja/neevraagsinne, bevat $[S p e c, C P]$ ' $n$ foneties leë wh-element. in wh-vraagsinne word [Spec,CP] leksikaal gevul deur ' $n$ verskuifde wh-frase. 'n Voorbeeld van die verskuiwing van ' $n$ wh-frase na [Spec,CP] is te sien in (2a). Aangesien [Spec,CP] reeds deur die woord wat gevul is, verhoog die subjek nie, maar bly regs van die werkwoord staan. In die geval van $\sin (5 \mathrm{a})$, is [Spec,CP] gevul deur die bywoord môre. Die subjek verhoog dus ook nie in hierdie sin nie en daarom bly die subjek regs van die werkwoord staan. VP-inisiële bywoorde soos dikwels verskyn regs van die werkwoord ondat die werkwoord bo-oor die bywoord verhoog, soos in (3a).

Vergelyk figuur 1 met figuur 2 wat die struktuur van die korresponderende sinne in Engels weergee. 


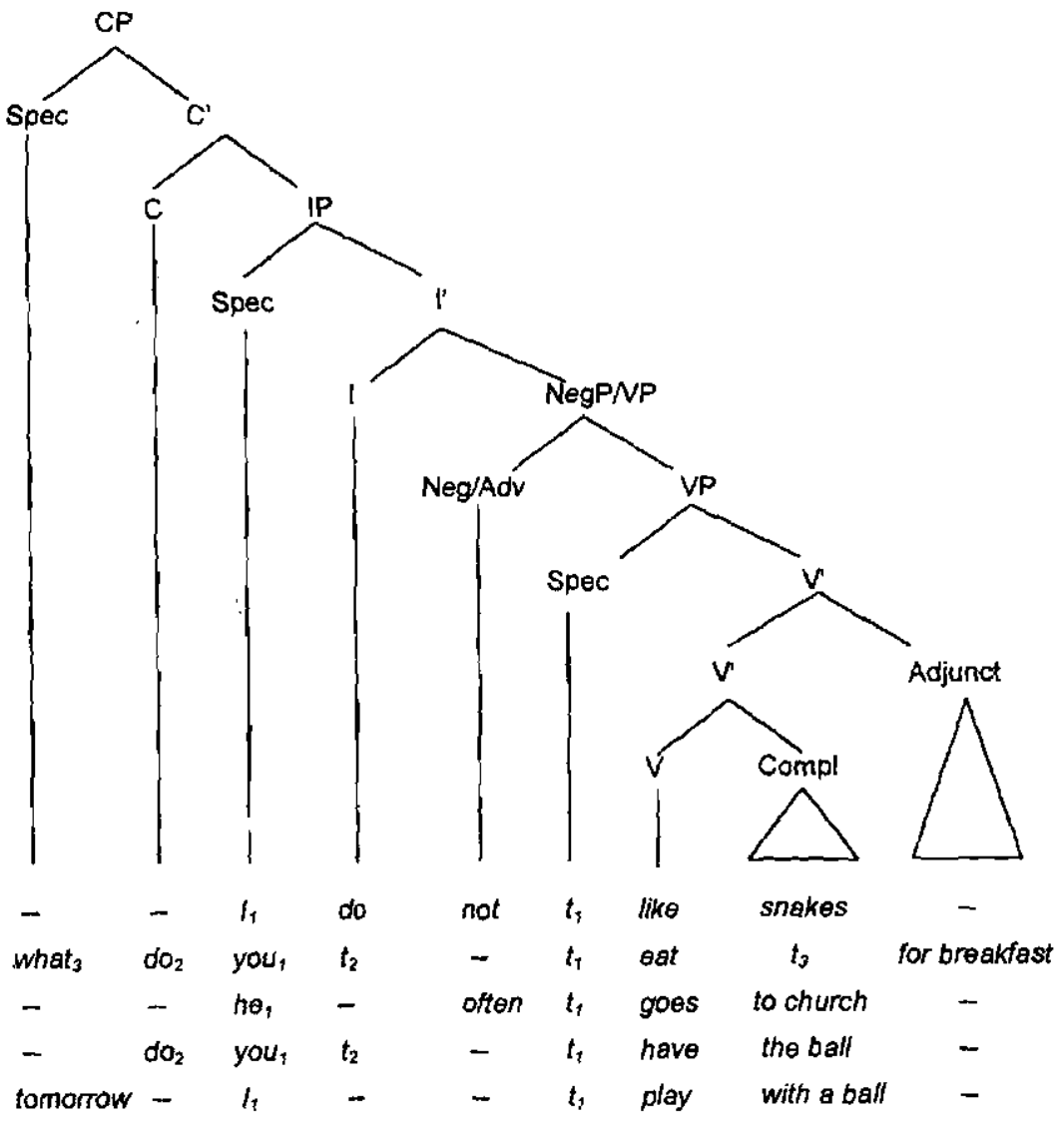

Flguur 2

1. Negatiewe sin:

2. Wh-vraag:

3. VP-inisiéle bywoord:

4. Ja/nee-vraagsin:

5. Sinsinisięle bywoord:
I do not like snakes.

What do you eat for breakfast?

He often goes to church.

Do you have the ball?

Tomorrow I play with a ball. 
In Engels skuif die subjek-NP, wat in die dieptestruktuur in [Spec,VP] staan, na [Spec,IP] in die oppervlakstruktuur soos te sien in figuur 2 (Cook 1996: 206). In Engels vind daar geen verhoging van hoofwerkwoorde plaas nie. 'n Negatiewe element kan dus nie regs van 'n hoofwerkwoord verskyn soos in (1b) nie en hoofwerkwoorde kan nie verby bywoorde verskuif soos in (3b) nie, maar staan onmiddelik regs van die negatiewe element en die bywoord, soos in (1c) en (3c) onderskeidelik. Daar vind ook geen hoofwerkwoordverhoging bo-oor die subjek plaas nie, soos uit (2b) blyk. Wanneer 'n bywoord aan die begin van die sin staan, verhoog die werkwoord in Afrikaans, terwyl die werkwoord in Engels nie verhoog nie, soos uit (5b) en (5c) blyk. Verhoging van hulpwerkwoorde soos have, be en do vind wel in Engels plaas in die geval van ja/nee-vrae soos in (4c) en wh-vrae soos in (2c) (Cook 1996: 210, 215).

Die verskille tussen Afrikaans en Engels wat hierbo beskryf en in figuur 1 en 2 geillustreer is, het te doen met ' $n$ verskil in die waarde van 'n parameter wat deur Pollock (1989) voorgestel is (White 1992(b): 276) en wat as die kongruensieparameter ("agreement parameter") bekend staan. Die waarde van die kongruensieparameter in Engels is "swak". Swak kongruensie blokkeer die toekenning van theta-rolle deur die werkwoord aan sy komplemente as die hoofwerkwoord uit die VP beweeg. Daarom kan die hoofwerkwoord in Engels nie uit die VP beweeg nie. Aangesien hulpwerkwoorde, anders as hoofwerkwoorde, geen theta-rolle het om oor te dra nie, mag hulle vryelik beweeg (Cook 1996:213; White 1992(b): 276). Indien die sin oor geen hulpwerkwoord beskik nie, word die substituut-hulpwerkwoord do ingevoeg. In Afrikaans het die kongruensieparameter " $n$ "sterk" waarde. Die hoofwerkwoord kan gevolglik in Afrikaans uit die VP beweeg en steeds theta-rolle aan sy komplemente toeken.

'n Afrikaanssprekende T2-leerder van Engels moet die waarde van die kongruensieparameter van "sterk" na "swak" verstel om sinne met die korrekte woordorde in die $\mathrm{T} 2$ te kan voortbring. Parameterwaardes is, volgens hipotese, met funksionele kategorieë geassosieer. Die kongruensieparameter is met die kategorie I $(=$ Inflection"), die hoof van IP, geassosieer (Cook en Newson 1996: 181). Korrekte woordorde in $T 2$-uitings is dus ' $n$ indirekte aanduiding van die teenwoordigheid van die funksionele kategorie I in die IT-grammatika. 


\subsection{Kongruensio}

Afrikaans en Engels verskil in nog 'n belangrike opsig. In Afrikaans is daar geen sigbare persoon- en getalooreenstemming tussen die subjek en die werkwoord nie, tenwyl Engels wel morfologies sigbare ooreenstemming het. Vergelyk byvoorbeeld die volgende:

\begin{tabular}{|c|c|}
\hline Engels: & Afrikaans: \\
\hline $1 \underline{a m}$ & $E k$ is \\
\hline $\mathrm{He} / \mathrm{she} /$ it is & $\mathrm{Hy} / \mathrm{sy} / \mathrm{dit}$ is \\
\hline You/they/we are & Jy / julle / hulle / ons is \\
\hline
\end{tabular}

Die voorkoms of afwesigheid van kongruensiemorfologie hang dikwels saam met die waarde van die kongruensieparameter (Cook 1996: 283). Normaalweg is die voorkoms van ryk kongruensiemorfologie in ' $n$ taal ' $n$ aanduiding dat die kongruensieparameter in die betrokke taal die "sterk" waarde het, terwyl die afwesigheid van (of gebrekkige) kongruensiemorfologie ' $n$ aanduiding is dat die parameter die "swak" waarde het. Engels is aansienlik minder ryk aan kongruensiemorfologie as ' $n$ taal soos byvoorbeeld Frans. Engels, maar nie Frans nie, vertoon dan ook woordordeverskynsels wat met die "swak" waarde van die kongruensieparameter geassosieer is.

Afrikaans het geen kongruensiemorfologie nie, wat 'n aanduiding behoort te wees dat die waarde van die kongnensieparameter in Afrikaans "swak" is. Tog vertoon Afrikaans woordordeverskynsels wat met die "sterk" waarde van die kongruensieparameter geassosieer word, soos in par. 2.1 aangetoon is. Dus, alhoewel kongruensie in Afrikaans nie morfologies uitgedruk word nie, word die voorkoms van werkwoordverplasing as genoegsame aanduiding aanvaar dat die kongruensieparameter in Afrikaans die "sterk" waarde het. Dit is die voorkoms van "sterk" kongruensie in Afrikaans wat die verskuiwing van die hoofwerkwoord uit VP moontlik maak.

Kongruensiemorfologie is bloot die sigbare realisering van abstrakte kongruensiekenmerke, soos persoon, getal en geslag, wat met die funksionele kategorie I geassosieer is. In ' $n$ taal met sigbare kongruensie, soos Engels, is die voorkoms van kongruensiemorfologie dus ' $n$ waarneembare aanduiding van die teenwoordigheid van l en sy projeksie IP (Grondin en White 1993: 121; Cook 1996: 181). 


\section{Hipotese}

Die volgende hipotese is vir hierdie studie gestel:

Die funksionele projeksie IP is vroeg reeds in die IT-grammatika varı T2leerders teenwoordig.

Hierdie hipotese verteenwoordig die siening van, onder andere, Schwartz en Sprouse (1996), Grondin en White (1993) en Lardière (1998) en is strydig met die siening van Vainikka en Young-Scholten (1996) dat slegs leksikale projeksies in die vroeë IT. grammatika teenwoordig is.

Die hipotese het twee toetsimplikasies vir Afrikaanssprekende T2-leerders van Engels. Die eerste toetsimplikasie het betrekking op woordorde. Indien IP in die IT-grammatika teenwoordig is, volg dit dat 1 (die hoof van IP) en sy geassosieerde kongruensieparameter in die IT-grammatika teenwoordig sal wees. Die kongruensieparameter kan een van twee waardes hê: die "sterk" waarde, oorgedra uit Afrikaans, die T1 van die leerders, of die "swak" waarde, wat die korrekte waarde vir die leerders se T2, Engels, is. In die bespreking in paragraaf 2.1 hierbo is aangetoon dat elkeen van hierdie waardes met 'n stel woordorde-eienskappe geassosieer is. Die volgende voorspelling word dus gemaak. Indien IP in die IT-grammatika teenwoordig is, sal leerders se T2-uitings of die woordorde-eienskappe in A. of die woordorde-eienskappe in $B$. hieronder vertoon:

\section{A. Eienskappe geassosieer met ole "sterk" T1-waarde van die parameter}

i. Finiete hoofwerkwoorde kom links van die negatief voor $-k y k \sin (1 a)$.

ii. Finiete hoofwerkwoorde kom links van die subjek-NP voor in vraagsinne - kyk sinne (2a) en (4a).

iii. Finiete hoofwerkwoorde kom links van VP-inisible bywoorde voor - kyk $\sin$ (3a).

iv. Finiete hoofwerkwoorde kom links van die subjek-NP voor in sinne met sinsinisielle bywoorde - kyk $\sin (5 a)$.

\section{B. Elenskappe geassosieer met dle "swak" T2-waarde van die parameter}

i. Hoofwerkwoorde kom nie links van die negatief voor nie - kyk sinne (1b) en (1c). 
ii. Hoofwerkwoorde kom nie links van die subjek-NP in vraagsinne voor nie - kyk sinne (2b) en (2c), asook sinne (4b) en (4c).

iii. Hoofwerkwoorde kom nie links van die VP-inisièle bywoorde voor nie - kyk sinne (3b) en (3c).

iv. Hoofwerkwoorde kom nie links van die subjek-NP in sinne met sinsinisiële bywoorde voor nie - kyk sinne (5b) en (5c).

Die voorspelling is dat die leerders se T2-uitings of die een of die ander van die twee stelle woordorde-eienskappe sal vertoon en nie 'n mengsel van die eienskappe in A. en B. nie. Die voorkoms van een van die stelle eienskappe in die T2-uitings van die leerders kan beskow word as ' $n$ aanduiding dat die kongruensieparameter en, by implikasie, die funksionele kategorie I (en sy projeksie IP) deel uitmaak van die ITgrammatika. Die aanwesigheid van slegs sekere van die eienskappe in of A. of B., of die voorkoms van eienskappe uit beide A. en B., kan beskou word as 'n aanduiding dat die betrokke parameter, en by implikasie die funksionele kategorie I (en sy projeksie IP), nie deel uitmaak van die IT-grammatika nie.

'n Tweede toetsimplikasie van die hipotese hierbo het met kongruensiemorfologie te doen. In paragraaf 2.2 hierbo is gemeld dat kongruensiemortologie die sigbare realisering is van abstrakte kongruensiekenmerke wat met die funksionele kategorie I geassosieer is. Die volgende voorspelling word dus gemaak. Indien IP in die ITgrammatika teenwoordig is, sal die uitings van T2-leerders van Engels kongruensiemorfologie vertoon.

\section{Metode}

Vyf-en-veertig sewejarige Afrikaanssprekende T2-leerders van Engels is vir die studie as proefpersone gebruik. Die kinders was graad 1-leerlinge aan twee Afrikaansmedium laerskole. Die ouers was almal Afrikaanssprekend en het net Afrikaans in die huis gebruik. Van die 45 kinders was 17 voorskools in 'n Afrikaanse kleuterskool of speelgroep (AKS), 16 was in 'n Engelse kleuterskool of speelgroep (EKS) en 12 was in 'n dubbelmedium kleuterskool of speelgroep (DKS). Die onderwyseresse in die EKS en DKS was almal Afrikaanssprekend, maar het Engels in die skool gepraat. In die DKS is die Afrikaanse en Engelse aanbieding van dag tot dag gewissel - een dag Afrikaans en een dag Engels. ' $n$ Groot persentasie van die kinders in die EKS was Afrikaanssprekend. 
Die kinders se blootstelling aan Engels ten tyde van die studie het die volgende behels: al die kinders het ongeveer twee en ' $n$ half uur onderrig in Engels per week ('n halfuur per dag) op skool ontvang. Die Engelse klasse was kommunikatief van aard en geen formele grammatika-onderrig is verskaf nie. Al die onderwyseresse se moedertaal was Afrikaans. Die kinders se blootstelling aan Engels buite die skool was oor die algemeen baie beperk. Die meeste kinders is slegs deur Engelse televisieprogramme aan Engels blootgestel. Hierdie blootstelling het tussen 1 uur en 14 uur per week gewissel.

Die ouers is gevra om ' $n$ vraelys in te vul. So is inligting bekom oor die mate waarin die kind buite die skool aan Engels blootgestel is, die taligheid van die kleuterskool of speelgroep waar die kind was, die ouderdom waarop die kind die eerste keer aan Engels as T2 blootgestel is en die duur van die kind se blootstelling aan Engels.

'n Vraelys is opgestel om die kinders se kennis van woordorde en kongruensie in Engels te bepaal (sien Bylae). Elke kind is individueel getoets en die antwoorde is deur ' $n$ enkele toetsafnemer neergeskryf. Die kinders se kennis van woordorde in die $\mathrm{T} 2$ is getoets aan die hand van die volgende tipes sinne:

i. Negatiewe sinne.

ii. Wh-vraagsinne.

iii. Ja/nee-vraagsinne.

iv. Sinne met sinsinisiële bywoorde.

v. Sinne met VP-inisièle bywoorde.

Verder het die vraelys items ingesluit wat daarop gemik was om aan te toon of die kinders weet dat Engels sigbare persoon- en getalkongruensie vertoon.

Beide kongruensie en woordorde is getoets met behulp van die volgende take:

A. Beoordeling van grammatikaliteit: Sinne 5.1 tot 5.12 (sien Bylae) is een vir een aan die T2-leerder voorgelees. Die T2-leerder moes vir elke sin aandui of dit grammatikaal is of nie.

B. Mondelinge produksie: In hierdie taak is die T2-leerder gevra om die sinne wat in taak $A$. deur hom/haar as ongrammatikaal beoordeel is, mondelings te verbeter. ' $n$ Tweede mondelingse taak het van die T2-leerder vereis om 'n aantal sinne (sinne 6.1. tot 6.11 in Bylae) wat deur die toetsafnemer in Afrikaans gelees is, mondelings in Engels te vertaal. 
C. Grammatikale voorkeurtaak: In hierdie taak het die toetsafnemer twee sinne voorgelees wat in grammatikale vorm verskil (sinne 7.1. tot 7.13 in Bylae). Die T2-leerder moes aandui (i) watter een van die twee reg klink, (ii) watter een van die twee verkeerd klink en (iii) indien albei reg of verkeerd klink, watter sin die beste klink.

Die produksietake en beoordelingstake (wat voorkeurtake insluit) is gebruik om vas te stel hoe die T2-leerders se onderliggende kennis van aspekte van die T2-grammatika daar uitsien. Die beoordelings- en produksietake het elk sy voor. en nadele. Die voordeel van beoordelingstake is dat leerders nie beperk word deur hul woordeskat en uitdrukkingsvermoè nie. Hulle grammatikale kennis kan gevolglik bepaal word op grond van sinne wat nie spontaan geproduseer sou word nie. Die voorkeurtake is by die beoordelingstake ingesluit sodat die T2-leerders die geleentheid kon kry om hul aanvaarding of verwerping van sekere woordordes en van kongruensiemorfologie aan te dui. Gesamentlik gee die resultate van die voorkeur- en beoordelingstake 'n goeie aanduiding van die T2-leerders se kennis van die grammatika van die T2.

Die nadeel van die tipe produksietake wat in hierdie studie gebruik is, is dat die uitinge van die T2-leerders nie spontaan was nie. Die voordeel egter, is dat hulle gedwing is om te poog om sinne te produseer wat hulle, miskien om bloot toevallige redes, nie tydens spontane taalgebrujk sou produseer nie. Die afwesigheid van ' $n$ spesifieke grammatikale vorm in ' $n$ spontane spraakmonster dui nie noodwendig op onvermoe om die betrokke vorm te produseer nie.

Indien die T2-leerder 'n probleem met woordeskat ondervind het, het die toetsafnemer die woordeskatitem verskaf, behalwe in gevalle waar die leerder daardeur tot die korrekte woordorde gelei sou word. Transkripsies van die T2-leerders se response is gekodeer volgens die korrektheid van die woordorde (die teenwoordigheid van hoofwerkwoordverskuiwing al dan nie), asook die korrektheid van die gebruik van kongruensiemorfologie (persoon en getal).

\section{Resultate}

Die taligheid van die kleuterskool waarin die kinders voorskools was, is gebruik as basis vir die ontleding van die resultate. Die kinders is in drie groepe ingedeel. Van die kinders was 17 in 'n Afrikaanse kleuterskool (AKS), 16 in 'n Engelse kleuterskool (EKS) en 12 in ' $n$ dubbelmedium kleuterskool (DKS). Die kinders wat in ' $n$ EKS was, is ingedeel volgens die aantal jare wat hulle daar deurgebring het. Daar was drie kinders 
wat net een jaar in 'n EKS was, vier kinders wat twee jaar in 'n EKS was, vyf kinders wat drie jaar in ' $n$ EKS was en vier kinders wat vier jaar in 'n EKS was.

\subsection{Hoeveelheid en aard van blootstelling aan Engels}

Op die tydstip toe die studie gedoen is, was die kinders se blootstelling aan Engels beperk. Die maksimum aantal ure blootstelling aan Engels was 22 uur per week, waarvan die grootste gedeelte bestaan het uit die kyk van Engelse televisieprogramme. Die minimum blootstelling aan Engels was 2,5 uur per week in die Graad 1 Engelse kJas op skool. Die totale aantal ure blootstelling aan Engeis per week (TOT AU) sluit in die aantal ure blootstelling aan formele onderrig in die skool, asook die aantal ure wat aan Engelse televisieprogramme, Engelse maats, vriende, stories, boeke en gesprekke binne die gesin spandeer is.

By die ontleding van die resultate is daar geen korrelasie gevind tussen TOT AU en prestasie in woordorde- en kongruensietake nie. In tabel 1 kan gesien word dat daar ' $n$ lae korrelasie is tussen elkeen van die tydsveranderlikes en prestasie in kongruensieen woordordetake.

\begin{tabular}{|l|c|c|c|c|c|c|}
\hline $\begin{array}{l}\text { Tyds- } \\
\text { veranderlikes }\end{array}$ & $\begin{array}{c}\text { Persentasie } \\
\text { in } \\
\text { kongruensie- } \\
\text { take }\end{array}$ & $\begin{array}{c}\text { Produksie } \\
\text { ven } \\
\text { kongruensie }\end{array}$ & $\begin{array}{c}\text { Beoordaling } \\
\text { van } \\
\text { kongruensle }\end{array}$ & $\begin{array}{c}\text { Persentasie } \\
\text { in } \\
\text { woordorde- } \\
\text { take }\end{array}$ & $\begin{array}{c}\text { Produksie } \\
\text { van } \\
\text { woordorde }\end{array}$ & $\begin{array}{c}\text { Becordeling } \\
\text { van } \\
\text { woordorde }\end{array}$ \\
\hline $\begin{array}{l}\text { Gereelde } \\
\text { blootst }\end{array}$ & .10 & -.16 & .29 & .33 & .41 & .31 \\
\hline Ure TV & -.22 & -.42 & -.19 & -.01 & -.10 & -.20 \\
\hline Oud na EKS & -.07 & -.09 & -.19 & .03 & -.06 & .05 \\
\hline $\begin{array}{l}\text { Oud van 10 } \\
\text { blootst }\end{array}$ & .00 & .18 & .00 & .02 & .11 & .09 \\
\hline TOT AU & .22 & .01 & .02 & -.07 & -.14 & -.16 \\
\hline Jare op EKS & $.57^{*}$ & .40 & $.63^{*}$ & .31 & .42 & .34 \\
\hline
\end{tabular}

Tabel 1 Korrelasies tussen blootstellingstyd aan Engels en prestasie in woordorde- en kongruensietake $\left(^{*}=\right.$ korrelasie is betekenisvol).

Gereelde blootst $\quad=\quad$ Gereeldheid van blootstelling aan Engels buite die skool.

Ure TV = Aantal uur Engelse televisieprogramme gedurende die week.

Oud na EKS $\quad=\quad$ Ouderdom van toetrede tot ' $n$ EKS

Oud van 1e blootst $=$ Ouderdom van eerste blootstelling aan Engels. Al die T2leerders se eerste blootstelling aan Engels was deur middel van die televisie op ' $n$ baie jong ouderdom.

TOTAU = Totale aantal ure huidige blootstelling aan Engels gedurende die week.

Jare op EKS = Aantal jaar wat die kind in 'n EKS was. 
Daar bestaan geen betekenisvolle korrelasie tussen prestasie in woordorde- en kongruensietake en enige van die veranderlikes wat na blootstellingstyo verwys nie. Die tydsveranderlike wat die hoogste korrelasies toon, is die aantal jare wat ' $n$ kind in 'n EKS was. Dit beteken dat die taligheid van die kleuterskool of speelgroep wat die kind bygewoon het, asook die aantal jare wat die kind in die EKS was, wel 'n invloed het op die verwerwing van woordorde en kongruensie by T2-leerders. Die tydsveranderike "Jare op EKS", is dus gebruik in die ontleding van die res van die resultate.

\subsection{Prestasie in woordorde- en kongruensietake}

Die 45 T2-leerders se prestasie in woordordetake (korrekte plasing van die werkwoord ten opsigte van die subjek) is met behulp van drie verskillende syfers uitgedruk:

Woordordeprestasie (WO\%): dit is bereken deur die samevoeging van die persentasies behaal in alle woordordebeoordeling. en produksietake tot in enkele persentasie vir woordorde.

- Beoordeling van woordordes (Wobeoord): dit is die prestasie net in woordordebeoordelingstake, uitgedruk as ' $n$ persentasie.

- Produksie van woordordes (WOprod): dit is die prestasie net in woordordeproduksietake, uitgedruk as 'n persentasie.

Die T2-leerders se prestasie in kongruensietake is verdeel in

- Kongruensieprestasie (KON\%): dit is bereken deur die samevoeging van die persentasies behaai in alle kongruerisiebeoordeling- en produksietake tot ' $n$ enkele persentasie vir kongruensie.

- Beoordeling van kongruensievorm (persoon en getal) (KONbeoord): dit is die prestasie net in kongruensiebeoordelingstake, uitgedruk as 'n persentasie.

- Produksie van kongruensievorm (persoon en getal) (KONprod): dit is die prestasie net in kongruensieproduksietake, uitgedruk as 'n persentasie.

\subsubsection{Globale prestasie in woordorde- en kongruensletake}

Oor die algemeen vaar die kinders wat in 'n EKS was beter in die beoordeling en produksie van kongruensie en woordorde as kinders wat in ' $n$ DKS was. Kinders wat in ' $n$ DKS was, doen weer beter as kinders wat in ' $n$ AKS was (fig.3). 


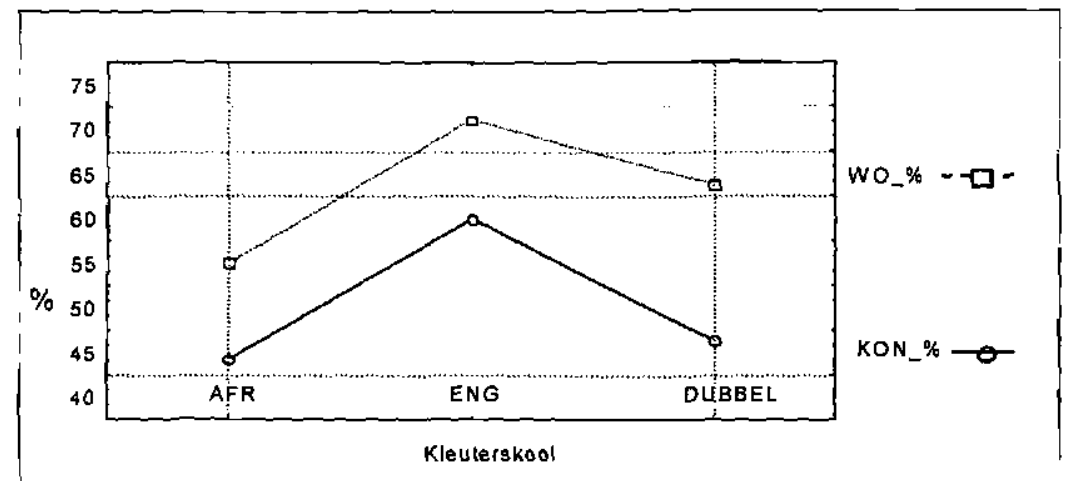

Figuur 3 Prestasie in woordorde- en kongruensietake deur kinders in AKS, DKS en EKS.

[Horisontale as: Taalmedium van kleuterskool]

[Vertikale as : Persentasie behaal in elk van die genoemde take]

Dit is duidelik dat prestasie in kongruensietake by kinders uit 'n AKS hoog (47\%) en prestasie in woordordetake nog hoer is $(56 \%)$. Kennis van beide kongruensie en woordorde is dus teenwoordig by kinders wat nog min blootstelling aan Engels gehad het. Daar is nie ' $n$ groot verskil in prestasie in kongruensietake tussen AKS-kinders (47\%) en DKS-kinders (49\%) nie, terwyl EKS-kinders aansienlik beter vaar (63\%). In woordordetake is daar 'n groter verskil tussen die prestasie van AKS-kinders $(57 \%)$ en die van DKS-kinders (66\%). Dit is ' $n$ aanduiding dat woordorde vinniger by DKSkinders verbeter as by AKS-kinders. Daarbenewens is dit 'n aanduiding dat woordordeprestasie vinniger as kongruensieprestasie verbeter met blootstelling aan Engels (vergelyk woordordeprestasie en kongruensieprestasie by DKS-kinders in figuur 3).

Die kinders wat die swakste gevaar het in woordordetake, was twee kinders uit 'n AKS wat tussen $20 \%$ en $30 \%$ van die woordordes (hoofsaaklik in beoordelingstake) korrek gehad het. Albei hierdie kinders het so min woordeskat tot hulie beskikking gehad, dat hulle feitlik geeneen van die produksietake kon uitvoer nie. Hulle het egter goed gevaar in die beoordelingstake, wat bygedra het tot die persentasie wat hulle uiteindelik in woordordetake behaal het. Hieruit kan afgelei word dat kennis van die verbod op werkwoordbeweging in Engeis baie vroeg reeds teenwoordig is. 


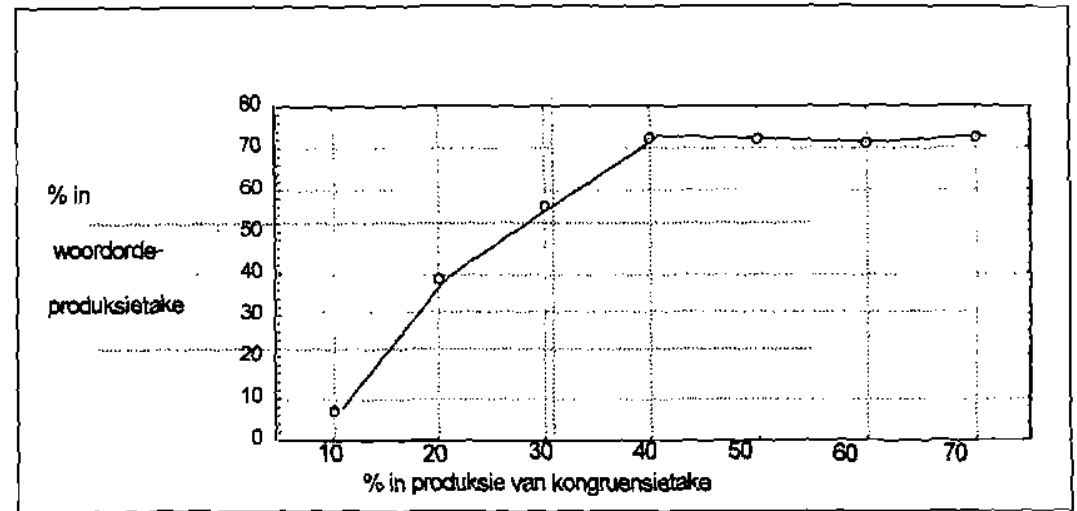

Figuur 4 Die verhouding tussen prestasie in woordorde- en prestasie in kongruensietake.

[Vertikale as: Persentasie in woordordeproduksietake]

[Horisontale as: Persentasie in kongruensieproduksietake]

Figuur 3 toon dat die kinders uit al die kleuterskole beter presteer in die produksie van korrekte woordorde as in die produksie van kongruensie. Dit word bevestig deur die grafiek in figur 4. Volgens figuur 4 het die kinders teen die tyd dat hulle reeds $70 \%$ van die woordordetake korrek uitgevoer hat, nog slegs $40 \%$ van kongruensietake korrek uitgevoer. Kennis van woordorde word dus gouer verwerf as kennis van kongruensie.

Die aantal jaar wat ' $n$ kind in ' $n$ EKS was, het ' $n$ invloed op prestasie in kongruensietake en woordordetake. Figuur 5 toon dat hoe langer die kind in 'n EKS was, hoe beter is sy beoordeling en produksie van korrekte woordorde en kongruensievarme. Die grootste verbetering in prestasie in kongruensie- en woordordetake vind in die eerste twee jaar op EKS plaas (fig. 5). 


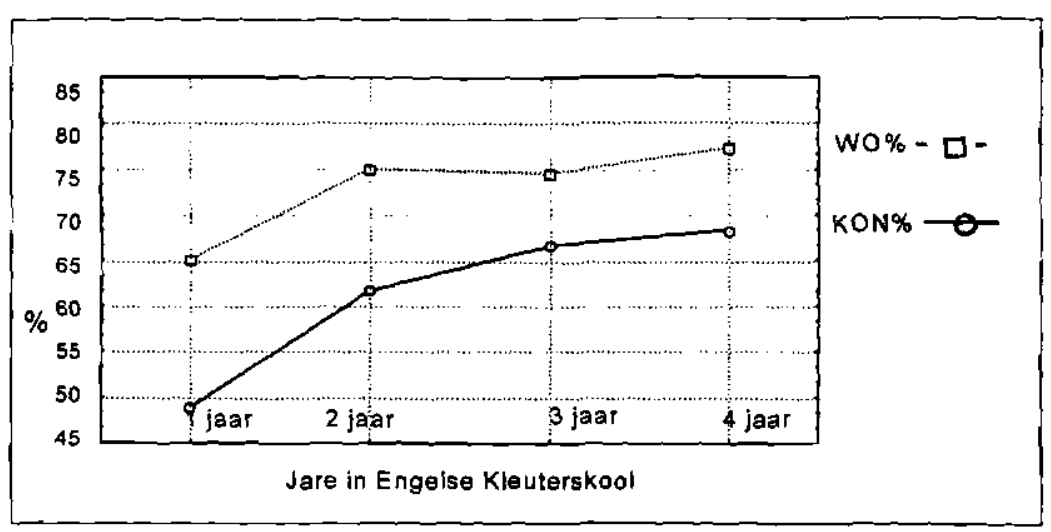

Figuur 5 Prestasie in kongruensie- en woordordetake by kinders wat een tot vier jaar in 'n EKS was.

[Horisontale as: Aantal jaar wat die kinders in ' $n$ EKS was]

[Vertikale as: Persentasje in woordorde-en kongruensietake]

Die kinders presteer oor die algemeen hoog in woordordetake vanaf die eerste jaar op EKS (fig. 5). Dit is ' $n$ aanduiding dat die T2-leerders baie gou (binne die eerste jaar) die kennis verwerf het dat die beweging van die hoofwerkwoord verbode is in Engels.

Samevattend kan gesé word dat die kinders oor die algemeen beter presteer in woordordetake as in kongruensietake. Prestasie in kongruensietake hou betekenisvol verband met die aantal jare wat ' $n$ kind in ' $n$ EKS was. Die korrelasie tussen prestasie in woordordetake en die aantal jare op EKS is kleiner en nie betekenisvol nie. Die afleiding kan dus gemaak word dat kennis van kongruensie in 'n groter mate afhanklik is van die tydperk van blootstelling aan Engels (hoe langer ' $n$ kind in ' $n$ EKS was, hoe beter die prestasie in kongruensietake), terwyl kennis van woordorde in 'n korter tyd van blootstelling aan die $T 2$ venwerf word.

\subsubsection{Beoordeling en produksie van woordorde}

Die kinders presteer almal beter in die beoordeling van woordorde as in die produksie van korrekte woordorde (fig. 6). Moedertaalwoordordes (die leerder verhoog die hoofwerkwoord in die T2 soos in die Ti) het by $29 \%$ van die AKS-kinders voorgekom en by $18 \%$ van die EKS-kinders. 


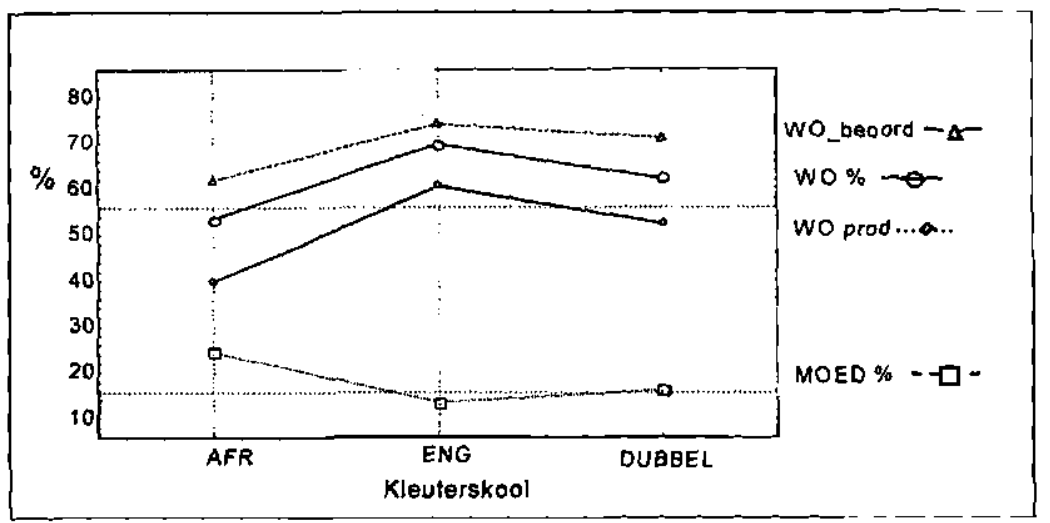

Figuur 6 Prestasie in verskillende woordordetake deur kinders wat in AKS, EKS WO $\%=\quad$ en DKS was.

MOED\% = Persentasie moedertaalwoordordes of T1-woordordes wat voorgekom het tydens T2-produksietake

WO prod $=$ Woordordeproduksie

WO beoord = Woordorde-beoordeling

[Horisontale as : Taaimedium van kleuterskool]

Nertikale as : Persentasie behaal in elk van die genoemde take]

Die hoe persentasie wat deur die AKS-kinders in woordordetake verwer is, veral in die beoordelingstake, toon weereens dat kennis van die verbod op werkwoordbeweging in Engels vroeg by T2-leerders teenwoordig is.

Volgens figuur $Y$ vind die grootste ontwikkeling t.o.v. beoordeling en produksie van woordorde binne die eerste een tot twee jaar in ' $n$ EKS plaas. Die grootste afname in die persentasie moedertaalwoordordes kom ook in hierdie tydperk voor. 


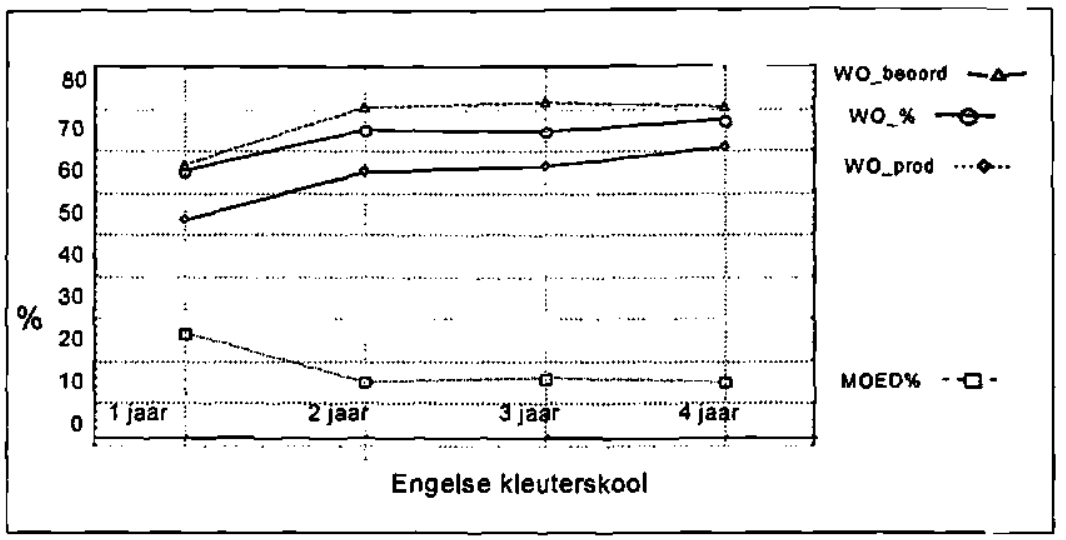

Figuur 7 Prestasie in woordordeproduksietake, woordorde-beoordelingstake, alle woordordetake en die persentasie moedertaalwoordordes by kinders wat een tot vier jaar in 'n EKS was.

[Horisontale as: Aantal jaar wat die kinders in 'n EKS was]

[Vertikale as: Persentasie behaal in elk van die genoemde take]

Voorbeelde van moedertaalwoordordes wat geproduseer is, is die volgende:
(6) T2: "As (how/like) you know, like my dog to play. (8 kinders)
T1: Soos jy weet, hou my hond daarvan om te speel.
(7) T2: "What eat you for breakfast? (7 kinders)
T1: Wat eet jy vir ontbyt?

Die hoofwerkwoord is deur 20 kinders in die volgende wh-vraag verhoog:

(8) T2: How many blues have you?

T1: Hoeveel van die bloues het jy?

Moedertaalwoordordes word dus wel deur T2-leerders gebruik, maar word binne 'n kort tydperk vervang met die korrekte T2-woordordes.

Voorbeelde van sinne wat deur 'n groot persentasie kinders korrek geproduseer is:
(9) I do not like snakes.
(Negatief)
(40 kinders)
(10) Don't kick the ball.
(Negatief)
(Almal)
(11) Yesterday / played with him. (Sinsinisiêle bywoord)
(38 kinders)

Slegs vyf kinders het 'n ongrammatikale T2-ekwivalent vir die sin Ek hou nie van slenge nie geproduseer. Van die vyf kinders was net een vir ' $n$ tydperk van een jaar in 'n EKS, terwyl die ander vier in 'n AKS was. Van die vyf het vier die sin "/ not like 
snakes geproduseer (do is uitgelaat, maar die hoofwerkwoord het nie verskuif nie) (sien fig. 8).

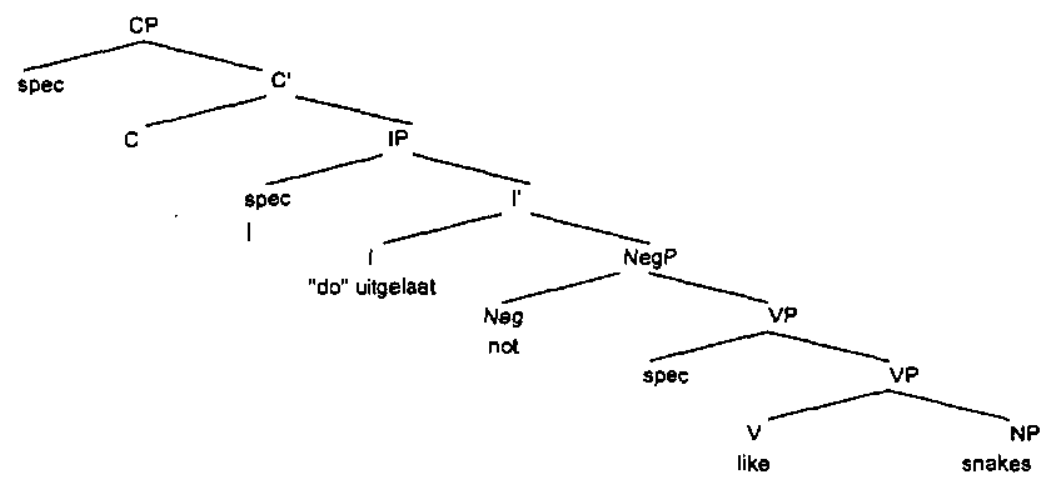

Figuur 8 Representasie van die sin "/ not like snakes.

Een kind het I like not snakes (werkwoordverhoging) geproduseer (sien fig. 9).

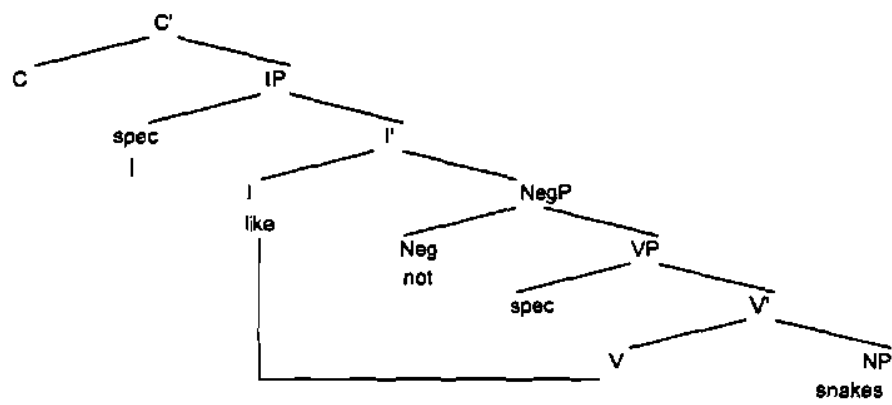

Figuur 9 Representasie van die $\sin \%$ like not snakes.

In die wh-vraagsinne het meer werkwoordverhogings plaasgevind. Daar was vyf kinders wat die hoofwerkwoord verhoog het en dus die moedertaalwoordorde *What eat you for breakfast? geproduseer het. Twee van hulle was in ' $n$ AKS, twee was in 'n DKS en een was in ' $n$ EKS (vir slegs een jaar). Drie AKS-kinders en twee DKS-kinders het die woordorde *What you eat for breakfast? geproduseer. In die laasgenoemde $\sin$ het hoofwerkwoordverhoging nie plaasgevind nie. Die $\sin$ is egter ongrammatikaal omdat do-invoeging nie toegepas is nie.

Die produksie en beoordeling van woordorde in die verskillende soorte sinne toon onderling ' $n$ sterk korrelasie soos in tabel 2 gesien kan word. 


\begin{tabular}{|c|c|c|c|c|c|c|}
\hline Veranderlike & $\begin{array}{c}\% \\
\text { Sinsinisiele } \\
\text { byw }\end{array}$ & $\begin{array}{l}\% \text { VP. } \\
\text { inisiele byw }\end{array}$ & $\%$ Wo & $\begin{array}{l}\% \text { Moedertaal } \\
\text { wo }\end{array}$ & $\%$ Vrae & $\% \mathrm{Neg}$ \\
\hline $\begin{array}{l}\text { \%Sinsinisiele } \\
\text { byw }\end{array}$ & 1.00 & $.61^{*}$ & $.79^{*}$ & $-.43^{*}$ & $.73^{*}$ & $69^{*}$ \\
\hline $\begin{array}{l}\% \text { VP-inisiele } \\
\text { byw }\end{array}$ & $.61^{*}$ & $1.00^{-}$ & $.46^{*}$ & $-.43^{\star}$ & $45^{\circ}$ & $.33^{*}$ \\
\hline$\%$ WO & $.79^{*}$ & $.46^{\circ}$ & 1.00 & $-.51^{\circ}$ & $.69^{\circ}$ & $.85^{*}$ \\
\hline $\begin{array}{l}\% \text { Moeder-taal } \\
\text { Wo }\end{array}$ &.$- \overline{43^{*}}$ & $-.43^{*}$ & $\overline{-.51^{*}}$ & 1.00 & $-.30^{\circ}$ & $-.41^{*}$ \\
\hline \% Vrae & $.73^{\circ}$ & $.45^{\star}$ & $.89^{\circ}$ & $-.30^{*}$ & 1.00 & $.62^{\circ}$ \\
\hline$\% \mathrm{Neg}$ & $69^{*}$ & $.33^{*}$ & $.85^{\circ}$ & $-.41^{\circ}$ & $.62^{*}$ & 1.00 \\
\hline
\end{tabular}

Tabel 2 Korrelasies in prestasie t.o.v. produksie en becordeling van woordorde in verskillende soorte sinne.

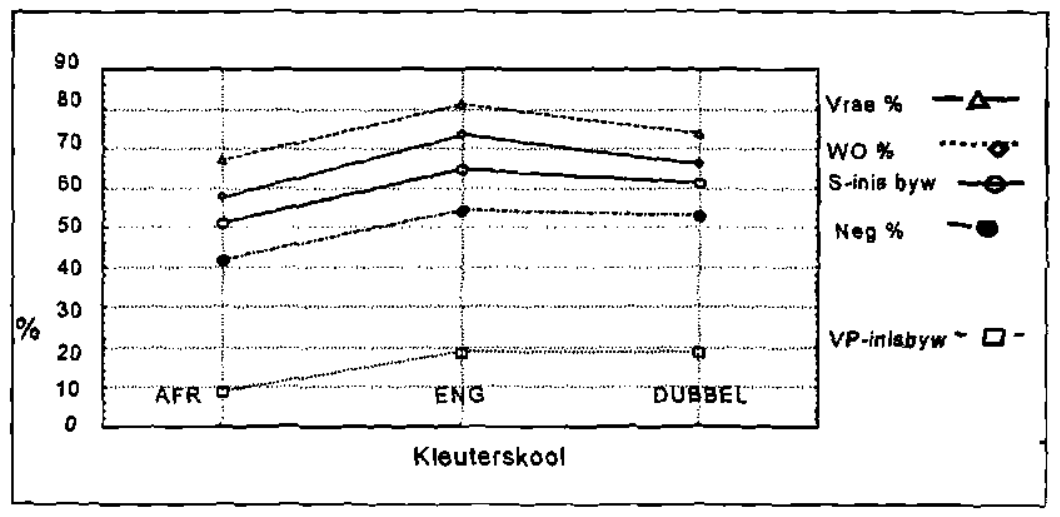

Figuur 10 Prestasie deur EKS-, AKS- en DKS-kinders in take wat kennis van woordorde in verskillende soorte sinne toets.

S-inis byw $=\quad$ Prestasie in take met sinsinisięle bywoord

VP-inis byw $=\quad$ Prestasie in take met VP-inisiële bywoord

Wo $\%=\quad$ Prestasie in woordordetake

Vrae $\%=\quad$ Prestasie in take met vraagsinne

$\mathrm{Neg} \%=\quad$ Prestasie in take met negatiewe sinne

[Vertikale as: Persentasie behaal in elke sinstipe]

[Honsontale as: Taalmedium van kleuterskool]

Die sterk korrelasies onderling tussen negatiewe sinne, vrae en sinne met sinsinisiele bywoorde, beteken dat indien 'n T2-leerder goed presteer in die produksie en beoordeling van enige van hierdie soorte sinne, hy in die res ook goed presteer. Figuur 10 toon dat prestasie ten opsigte van die pasgenoemde soorte sinne hoog is in vergelyking met die prestasie ten opsigte van sinne met VP-inisiele bywoorde. Díe beweging van die hoofwerkwoord bo-oor VP-inisielle bywoorde word dus geredelik 
toegelaat. Kinders uit 'n EKS en DKS presteer beter as kinders uit 'n AKS in take met VP-inisiële bywoorde. Dit bevestig dat die mate van blootstelling aan die T2 ' $n$ gering positiewe invloed het op die plasing van werkwoorde in sinne met VP-inisiële bywoorde.

Al die kinders het die volgende sin met 'n VP-inisiële bywoord tydens die beoordelingstaak goedgekeur:

(12) T2: 'She goes often to the hospital.

T1: Sy gaan dikwels hospitaal toe.

Al die kinders het die volgende woordorde tydens die produksietaak geproduseer:

(13) T2: *He goes often to church.

T1: Hy gaan dikwels kerk toe.

By die voorkeurtaak het die kinders egter aansienlik beter gevaar. Die korrekte woordorde (14b) is deur $50 \%$ (20) van die kinders gekies.

(14) (a) Linda eats always an ice-cream.

(b) Linda always eats an ice-cream.

Daar is nie ' $n$ liniêre verband gevind tussen die aantal jare blootstelling aan Engels en prestasie in take met VP-inisiele bywoorde nie.

\subsubsection{Beoordeling en produksie van kongruensie}

Produksie en beoordeling van kongruensie toon dieselfde grafiekvorm as wat by woordorde voorgekom het, naamlik kinders uit 'n EKS presteer beter as kinders uit 'n DKS, wat weer beter vaar as kinders uit ' $n$ AKS. 


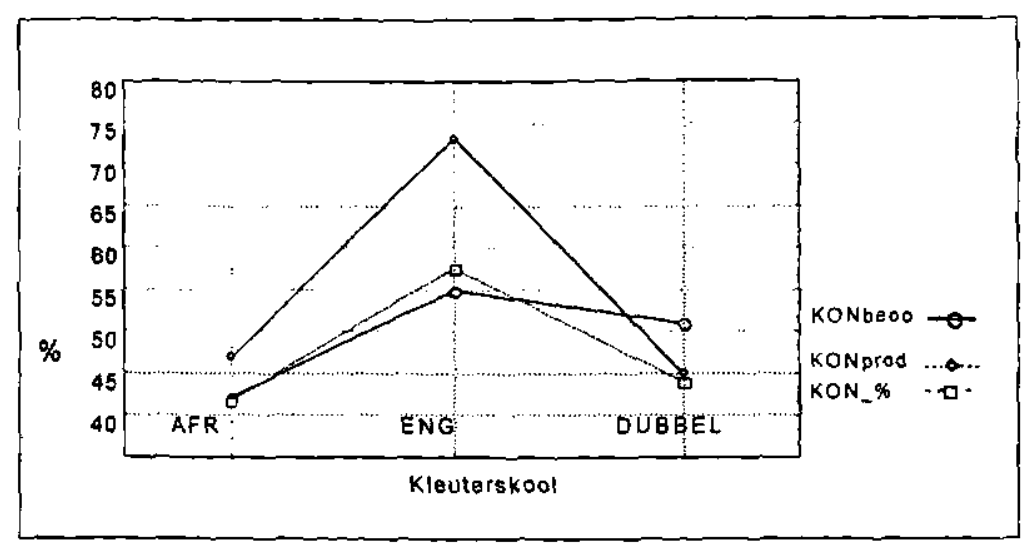

Figuur 11 Prestasie in kongruensietake deur kinders uit 'n EKS, AKS en DKS.

[Horisontale as : Taaimedium van kleuterskoo!]

[Vertikale as : Persentasie behaal in kongruensietake]

'n interessante verskynsel was die verhouding tussen kongruensiebeoordeling en kongruensieproduksie by die kinders uit die verskillende kleuterskole. Die kinders in die AKS en EKS het swakker gevaar met die beoordeling van kongruensie as met die produksie van kongruensie (fig. 11). 'n Sin wat byvoorbeeld deur almal verkeerd beoordeel is, is

(15) T2: There are a swimmingpool.

T1: Daar is ' $n$ swembad.

Nie 'n enkele kind het die kongruensievorm are in voorbeeld (15) as ongrammatikaal beskou nie. Wanneer hulle egter sinne geproduseer het, het hulie die korrekte kongruensievorm gebrujk en het daar selfs spontane korreksie voorgekom, byvoorbeeld "/s you glad ... are you glad it is holiday?". Aangesien geeneen van die kinders enige formele onderrig ten opsigte van kongruensie ontvang het nie, kan daar aangeneem word dat die kinders se korrekte gebruik van kongruensie onbewuste kennis van hierdie aspek van die $T 2$ weerspieël.

Anders as by die beoordelingstaak, is daar by die voorkeurtaak slegs enkele kinders wat foutiewe persoon- en getalkongruensievorme gekies het.

(16) (a) The birds is singing.

(b) The birds are singing. (B kinders kies (16a))

(17) (a) "The dog wag his tail.

(b) The dog wags his tail. (10 kinders kies (17a)) 
Wanneer daar dus 'n keuse van twee vorms aan die proefpersoon voorgehou is, het die meerderheid die regte keuse gemaak. Wanneer hulle egter ' $n$ sin in isolasie moes beoordeel, was hulle nie bewus van die foutiewe kongruensievorm nie.

Ten slotte vat die uitbeelding in figuur 12 die resultate van hierdie studie saam. Die T2leerders in die studie se globale prestasie in woordordetake word in verband gebring met die volgende:

1. Prestasie in woordordeproduksie en -beoordelingstake: Daar bestaan ' $n$ positiewe korrelasie tussen prestasie in woordordetake ten opsigte van alle soorte sínne en globale prestasie in die produksie en beoordeling van woordordes. Figuur 12 toon ook aan dat daar ' $n$ sterk korrelasie bestaan tussen die korrekte beoordeling en korrekte produksie van woordorde. Hoe beter die prestasie in beoordelingstake is, hoe beter is die prestasie in produksietake. Beoordeling van woordorde is beter as die produksie daarvan.

2. Prestasie in kongruensietake: Daar bestaan ook ' $n$ sterk korrelasie tussen prestasie in woordordetake en prestasie in kongruensietake. Dit is grafies in figur 12 te sien. Hoe beter die prestasie in woordordetake, hoe beter is die prestasie in kongruensietake.

3. Prestasie ten opsigte van sinne met VP-inisiële bywoorde: Daar is geen korrelasie te sien tussen korrekte werkwoordplasing in sinne met VP-inisiële bywoorde en prestasie in woordordetake nie. Slegs by die T2-leerders wat die beste gevaar het in woordordetake, was daar ' $n$ toename te sien in prestasie ten opsigte van sinne met VP-inisiële bywoorde.

4. Blootstelling aan Engels (buite die kleuterskool): Daar is in hierdie studie geen verband gevind tussen die hoeveelheid blootstelling aan Engeis buite die kleuterskool (TOT AU) en prestasie in woordordetake nie. Dit is interessant dat die aantal ure blootstelling aan Engelse televisieprogramme geen invloed op die prestasie in woordordetake het nie. 


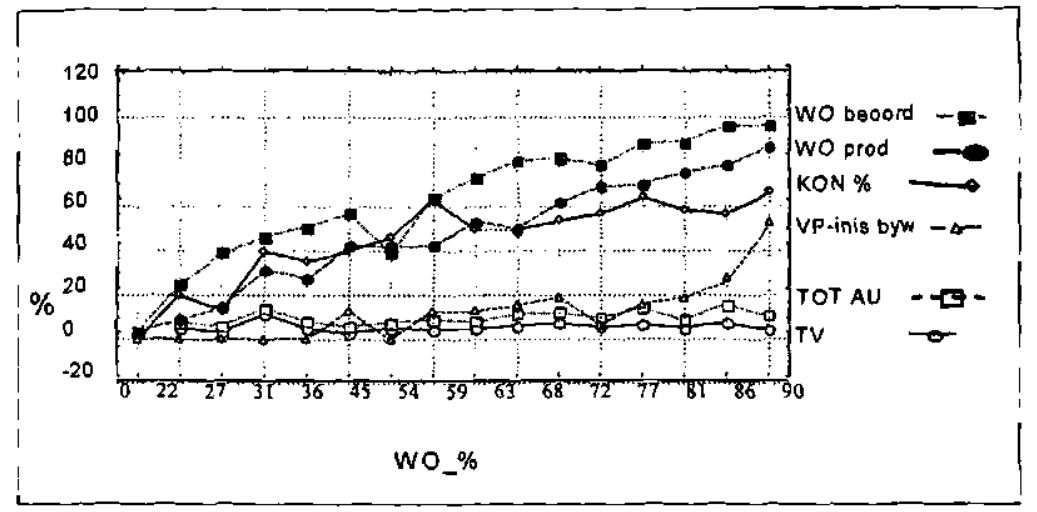

Figuur 12 Die verhouding tussen globale prestasie in woordordetake enersyds en, andersyds, prestasie in kongruensietake, woordordeproduksie en -beoordelingstake, prestasie t.o.v. sinne met VP-inisiéle bywoorde, totale aantal ure blootstelling aan Engels en aantal ure Engelse televisieprogramme.

\section{Gevolgtrokkings}

Die resultate van hierdie studie ondersteun die hipotese dat die funksionele projeksie IP vroeg teenwoordig is in die IT-grammatika van T2-leerders, aangesien beide toetsimplikasies van die hipotese deur die resultate bevestig word.

Toetsimplikasie 1 lui soos volg: indien IP in die IT-grammatika teenwoordig is, sal die uitings van T2-leerders van Engels al en net dié woordorde-eienskappe vertoon wat met of die "sterk" (T1) of die "swak" (T2) waarde van die kongruensieparameter geassosieer is. Dit wil sé, die hipotese voorspel dat T2-uitings uitstuitlik die woordordeeienskappe van die $\mathrm{T} 1$ in $\mathrm{A}$. of uitsluitlik die woordorde-eienskappe van die T2 in $\mathrm{B}$. in paragraaf 3 hierbo sal vertoon. By die meeste van die kinders se uitings is eienskappe van beide $A$ en $B$ in ' $n$ meerdere of mindere mate teenwoordig. ${ }^{5}$ Die studie het nogtans verskeje gegewens opgelewer wat daarop dui dat die IT-grammatikas van al die T2leerders in die studie wel 'n waarde vir die kongruensieparameter insluit.

1. Daar is sterk korrelasies gevind tussen die T2-leerders se prestasie in woordordetake in vraagsinne, negatiewe sinne en sinne met sinsiniële bywoorde. Slegs enkele leerders het foutiewe woordordes in negatiewe sinne en vraagsinne geproduseer. Konsekwente produksie en herkenning van korrekte woordorde in verskillende soorte sinne dui daarop dat die leerders met 'n vaste waarde (in hierdie geval die "swak" T2-waarde) vir die kongruensieparameter opereer. 
2. As die EKS-kinders en tien van die twaalf DKS-kinders het $100 \%$ konekte beoordeling en 'n hoë persentasie korrekte produksie van al die woordordes wat met die "swak" T2-waarde van die kongruensieparameter geassosieer word, behaal (d.i. die woordorde-eienskappe in B.). Die DKS-kinders het al die sinne, met die uitsondering van sinne met VP-inisiële bywoorde, korrek beoordeel. Dit is dus duidelik dat kinders met langer blootstelling aan Engels (d.i. die EKS-kinders en die meeste DKS-kinders), wie se IT-grammatika al verder ontwikkel het, konsekwent die korrekte T2-woordordes herken en produseer. Om dit te kan doen, moet die T2-leerders oor kennis van die T2parameterwaarde beskik.

3. Slegs twee kinders uit die DKS-groep se uitings in produksietake het die woordorde-eienskappe in A. vertoon. In die beoordelingstake het hulle egter blyke gegee van kennis van die woordorde-eienskappe in B. Hierdie twee kinders was slegs een jaar in ' $n$ DKS en het, in teenstelling met die res van die groep, geen Engelse maats in die kleuterskool gehad nie. Slegs $29 \%$ van die AKS-groep se uitings in die woordordeproduksietake het woordorde.eienskappe van A. vertoon. Van die sewentien AKS-kinders, het slegs twee se uitings in beide die produksie- en die beoordelingstake al die woordordeeienskappe van A. vertoon. Hierdie twee kinders het egter oor so min T2woordeskat beskik, dat hulle feitlik geen produksietake kon uitvoer nie. Dit is opvallend dat dit kinders met ' $n$ uiters kort blootstelling aan Engels is (die AKSkinders sowel as die twee genoemde DKS-kinders) wat meestal T1-woordordes gebruik. Die gevolgtrekking wat hieruit gemaak kan word Is dat die ITgrammatikas van hierdie T2-leerders, ' $n$ aanvangsgrammatika is waarin die T1parameterwaarde steeds voorkom.

Al die gegewens wat in 1. tot 3. genoem word, dui daarop dat die T2-leerders in die studie kennis dra van klusters van grammatikale eienskappe wat met 'n bepaalde waarde van die kongruensieparameter, hetsy die T2-waarde of die T1-waarde. geassosieer is. Die implikasie hiervan is dat die IT-grammatikas van die betrokke T2leerders wel ('n waarde vir) die kongruensieparameter insluit (White 1992a: 223). Aangesien die kongruensieparameter met die funksionele kategorie 1 geassosieer is, kan die gevolgtrekking gemaak word, dat I deel uitmaak van die IT-grammatika.

Die bevindings in 2. en 3. genoem, dui verder daarop (i) dat T2- leerders aanvanklik die T1-parameterwaarde na die IT-grammatika oordra, en (ii) dat die parameter heel vroeg na die eerste blootstelling aan die T2 oor ingestel word. Die verandering van T1- 
woordordes na T2-woordordes vind feitlik oombliklik plaas en nie inkrementeel oor 'n langer tydperk nie. Die meeste AKS-kinders gee reeds na minimale blootstelling aan Engels, in die beoordelingstake sowel as in sommige van die produksietake blyke daarvan dat hulle met die "swak" T2-waarde van die kongruensieparameter opereer. Slegs twee kinders uit die AKS-groep opereer nog met die "sterk" parameterwaarde van die $T 1$ in bejde produksie- en beoordelingstake. Die voorkoms van moedertaalwoordordes neem ook vinnig af tydens die eerste jaar op EKS (van $28 \%$ tot $15 \%$ ). Dit is 'n aanduiding van hoe vinnig die kongruensieparameter se waarde oor ingestel word vanaf die "sterk" waarde wat werkwoordverhoging in Afrikaans tot gevolg het, na die "swak" waarde wat werkwoordverhoging in Engels verbied.

Die resultate ten opsigte van sinne met VP-inisiële bywoorde verdien kortliks bespreking. Die T2-leerders in die studie het aansienlik swakker presteer in take wat korrekte plasing van die hoofwerkwoord teenoor VP-inisible bywoorde vereis, as in woordordetake met sinne waarin negatiewe elemente, vraagwoorde en sinsinsiële bywoorde voorkom. Die verskynsel wat White waargeneem het by Franssprekende T2-leerders van Engels (White 1991: 134 - 135; White 1989: 150; Cook 1996: 211; White 1989: 135; White 1991: 137; White 1992: 286) kom klaarblyklik ook voor by Afrikaanssprekende T2-leerders van Engels. Slegs 10\% van die AKS-kinders en 20\% van die EKS- en DKS-kinders het die werkwoord korrek gepiaas in sinne met VP. inisiele bywoorde. Die meeste T2-leerders is dus onder die indruk dat die hoofwerkwoord in Engels bo-oor die bywoord mag verhoog, terwyl die hoofwerkwoord by negatiewe sinne, vraagsinne en sinne met sinsinisialle bywoorde nie mag verhoog nie. In hul vertaling van die $\sin H y$ gaan dikwe/s kerk toe (Taak 6.10) het agt kinders gebruik gemaak van hulpwerkwoorde. Anders as in die geval van die ander sinstipes, is die hoofwerkwoord egter verhoog en is uitings soos * $\mathrm{He}$ is going often $_{t_{l}}$ to church geproduseer. Waarom T2-leerders van Engels die verhoging van die hoofwerkwoord in sinne met VP-inisiële bywoorde toelaat, maar nie in ander tipes sinne nie, is nie duidelik nie. 'n Moontlike verklaring is dat die waargenome woordorde met foutiewe bywoordplasing te doen het, eerder as met werkwoordplasing. Bywoorde kan in in verskeidenheid van sinsposisies voorkom in Engels, byvoorbeeld Offen he goes to church in a jogger / He often goes to church (in a jogger) / He goes (to church) often / He goes directly to church. Dit is moontlik dat leerders wat "He goes often to church produseer, nie werkwoordverhoging toepas nie, maar (verkeerdelik) aanneem dat often in dieselfde posisie as directly (in He goes directly to church) kan voorkom. Met die ontleding van die resultate is daar nie ' $n$ liniêre verband gevind tussen die aantal jare blootstelling aan Engels en prestasie in sinne met VP-inisiële bywoorde nie. Dit mag 'n 
aanduiding wees dat die foutiewe woordorde in sinne met VP-inisièle bywoorde kan fossileer.

Toetsimplikasie 2 lui soos volg: indien IP in die IT-grammatika teenwoordig is, sal kongruensiemorfologie in die uitings van die T2-leerders van Engels voorkom. Die resultate toon dat selfs kinders met in minimale T2-kompetensie, in die beoordelingstake ' $n$ voorkeur toon vir sinne waarin die korrekte kongruensievorme voorkom. Prestasie in kongruensietake is selfs by kinders wat in ' $n$ AKS was (48\%) en dus min blootstelling aan Engels as T2 gehad het, relatief hoog. Oor die algemeen het die kinders beter gevaar met die produksie van korrekte kongruensievorme as met die beoordeling daarvan (met uitsondering van die twee kinders uit die AKS-groep wat feitlik geen produksietake kon uitvoer nie vanwee hulle gebrekkige Engelse woordeskat). ${ }^{~ D i e ~ o u t o m a t i e s e ~ e n ~ s p o n t a n e ~ p r o d u k s i e ~ v a n ~ k o r r e k t e ~ k o n g n u e n s i e v o r m e ~}$ deur die T2-leerders in die studie is 'n aanduiding dat die funksionele projeksie IP vroeg reeds in die IT-grammatika van T2-leerders teenwoordig is. Hierdie bevinding is in ooreenstemming met die bevinding van studies soos diê van Gavruseva en Lardière (1996: 225), Lardière (1998: 1), Grondin en White (1993: 121), Schwartz en Sprouse (1996: 46) en White (1989: 50).

'n Verdere waarneming wat tydens hierdie studie gemaak is, is dat die T2-leerders beter presteer in woordordetake ( $70 \%$ korrek) as in kongruensietake ( $40 \%$ korrek) - kyk fig. 3 en 4. Kongruensie en woordorde is met dieselfde parameter (die kongruensieparameter) geassosieer. 'n Mens sou dus verwag dat die verwerwing van T2kongnuensiemorfologie en T2-woordorde min of meer gelyktydig sou plaesvind. Uit die T2-leerders se prestasie in woordordetake kan afgelei word dat die waarde van die kongruensieparameter vroeg reeds oor ingestel word. Daarteenoor is die T2-leerders se gebruik van (korrekte) kongnuensiemorfologie wisselvallig. Studies deur Lardiere (1998: 20) en Gavruseva en Lardière (1996: 227), het soortgelyke resultate opgelewer. Ook hulle het gevind dat korrekte T2-woordorde voor korrekte T2. kongruensiemorfologie voorkom. Lardière (1998: 21) verklaar hierdie verskynsel soos volg. Anders as kennis van woordorde, is kennis van kongnuensiemorfologie leksikale kennis. Lardière (1998: 2, 23) beweer dat verwerwing van die leksikale items waardeur kongruensie sigbaar gerealiseer word, onafhanklik is van die verwenwing van die (sintaktiese) kennis dat kongruensie in die taal voorkom. Die nie-voorkoms van kongruensiemorfologie is dus nie ' $n$ aanduiding dat die onderliggende sintaktiese kennis nog nie verwerf is nie (Lardière 1998: 2). Die T2-leerders in hierdie studie het wel deeglik getoon dat hulle oor die nodige abstrakte sintaktiese kennis beskik, $\mathrm{d}$. 
kennis van die T2-waarde van die kongruensieparameter, al het hulle nog nie 'n goeje beheersing van die leksikale items waardeur kongruensie in die T2 uitgedruk word nie.

\section{Slot}

Om op te som: die resultate van die studie dui daarop dat T2-leerders in die vroegste stadium van T2-verwerwing reeds oor ' $n$ vaste waarde vir die kongruensieparameter beskik. Na ' $n$ kort periode waarin van die T1-parameterwaarde gebruik gemaak word, word die parameterwaarde na dié van die T2 verstel. Dit blyk uit die hoë voorkoms van korrekte woordorde in verskillende soorte sinne, asook die teenwoordigheid van kongruensiemorfologie binne die eerste twee jaar van blootstelling aan die T2. Die resultate bevestig dat die funksionele projeksie IP wel vroeg in die IT-grammatika van T2-leerders teenwoordig is.

\section{VOETNOTE}

${ }^{1}$ Hierdie artikel is ' $n$ aansienlik hersiene weergawe van ' $n$ werkstuk wat in 1998 deur Elza Hattingh aan die Departement Algemene Taalwetenskap van die Universiteit van Stellenbosch voorgele is ter gedeeltelike voldoening aan die vereistes vir die graad MA in Algemene Taalwetenskap. Cecile le Roux was die studieleier.

2 Deurdat die subjek, ' $n$ objek of ' $n$ bywoord in die Spec-posisie van die CP geplaas word, kan die finiete werkwoord in die tweede posisie van die sin verskyn. Die Spec van die CP moet dus altyd gevul wees om ' $n$ V2-woordorde daar te stel. Die werkwoord beweeg uit die VP en laat die objek agter. As die subjek na die sinsinisielle posisie beweeg, verkry ons 'n SVO-oppervlakwoordorde in hoofsinne (Cook 1996: 222) byvoorbeeld:

$$
\begin{array}{ll}
\text { Dieptestruktuur: } & \text { Ek nie van slange hou nie } \\
\text { Oppervlakstruktuur: } & \text { Ek hou nie van slange } t \text { nie. }
\end{array}
$$

Die gebruik van $t$ toon die posisie aan waanin die finiete werkwoord in die dieptestruktuur gestaan het.

${ }^{3}$ Die aanname word gemaak dat Afrikaans onderliggend ' $n$ SOV-woordorde het om voorsiening te maak vir die posisie van die finiete werkwoord in bysinne soos $\mathrm{Hy}$ vra of ok van slange hou. Daar word aangeneem dat die subjek-NP in die dieptestruktuur in [Spec,VP] staan vanwaar dit na [Spec, IP] skuif. Die kategorie IP ("inflectional phrase") word dikwels in 'n AgrP ("agreement phrase") en 'n TP ("tense phrase") verdeel - kyk 
bv. Cook \& Newson (1996: hfst 8). Ter wille van eenvoud word daar in hierdie artikel van 'n onverdeeide IP in boomdiagramme gebruik gemaak.

${ }^{4}$ Die status van die tweede nie in Afrikaans is kontensieus en daar sal nie in hierdie artikel verder op die kwessie ingegaan word nie. Dit word dus in alle strukture weggelaat.

${ }^{5}$ Daar is een EKS-kind wie se prestasie in produksie- en beoordelingstake al die eienskappe van A insluit, en twoe AKS-kinders wie se prestasie in produksietake op die teenwoordigheid van al die eienskappe van $B$ dui. Die EKS-kind was slegs een jaar in ' $n$ Engelse kleuterskool.

6 ' $n$ Moontlike verkiaring vir hierdie resultate kan wees dat die learders nog te min bewuste of formeel aangeleerde kennis van die T2 het om korrekte (bewuste) oordele oor grammatikale vorme te kan maak. In die (onbewuste) IT-grammatika is egter alreeds die nodige kennis - daarom die beter prestasie in take soos produksietake wat ' $n$ beter weerspieelling is van die IT-grammatika (d.i. kennis van die T2 eerder as kennis oor die T2).

\section{VERWYSINGS}

Cook, Vivian and Mark Newson. 1996. Chomsky's Universal Grammar: An introduction. Oxford: Blackwell.

Gavruseva, L. and D. Lardière. 1996. The emergence of extended phrase structure in child L2 acquisition. BUCLD 20 Proceedings: $225-236$.

Grondin, Nathalie and Lydia White. 1993. Functional categories in child L2 acquisition of French. McGill Working Papers in Linguistics 9: 121 - 145.

Lardière, D. 1998. Case and tense in the 'fossilized' steady state. Second Language Research 14(1): 1-26.

Schwartz, Bonnie D. and Rex A. Sprouse. 1996. L2 cognitive states and the Full Transfer/Full Access model. Second Language Research 12(1): 40-72.

Towell, Richard and Roger Hawkins. 1994. Approaches to second language acquisition. Clevedon: Multilingual Matters.

Vainikka, Anne en Martha Young-Schoiten. 1996. Gradual development of L2 phrase structure. Second Language Research 12(1): 7 - 39.

White, Lydia. 1989. Universal Grammar and second language acquisition. Amsterdam/ Philadelphia: John Benjamins. 
White, Lydia. 1991. Adverb placement in second language acquisition: Some effects of positive and negative evidence in the classroom. Second Language Research 7: $133-161$

White, Lydia. 1992(a). Universal Grammar: Is it just a new name for old problems? In Gass, S.M. and L. Selinker (eds). Language transfer in language leaming. Amsterdam/Philadelphia: John Benjamins, 217 - 232.

White, Lydia. 1992(b). Long and short movement in second language acquisition. Canadian Journal of Linguistics 37(2): 273 - 286.

\section{BYLAE}

\section{VRAELYS AAN T2-LEERDERS}

1. Naam en Van

2. Ouderdom:

3. Skool

4. Telefoon: (H) $(W)$

5. Dui aan watter sinne verkeerd is in Engels. As 'n sin verkeerd is, gee die regte sin. 5.1. The cat sleep on the bed.

5.2. What does the cat do on the bed?

5.3. It takes not long to go to school.

5.4. Luke eats a peach.

5.5. What did Mary look at?

5.6. There are a big swimmingpool

5.7. Yesterday had he with the dog played.

5.8. The four girls likes the cat.

5.9. John will a book buy.

5.10. I like not to look at a fight.

5.11. She goes often to hospital.

5.12. Go you to a movie?

6. Sit die sinne oor in Engels.

6.1. Wat eet jy vir ontbyt?

6.2. Gee vir my die botter aan asseblief.

6.3. Is jy bly dit is vakansie?

6.4. Moenie die bal skop nie.

6.5. Hoeveel van die bloues het jy?

6.6. Het sy ook nou een? 
6.7. Gister het ek met hom gespeel.

6.8. Vandag het Sally ' $n$ boek gekoop.

6.9. Die seun is deur die hond gebyt

6.10. Hy gaan dikwels kerk toe.

6.11. Soos jy weet, hou my hond daarvan om te speel.

7. Watter van die voigende sinne is reg in Engels? Maak ' $n$ kruisie by elke regte sin.

7.1. (a) Linda eats always an ice-cream.

(b) Linda always eats an ice-cream.

7.2. (a) Do you like to swim?

(b) Like you to swim?

7.3. (a) The girls like not the rose.

(b) The girls do not like the rose.

7.4. (a)The dog wag his tail.

(b) The dog wags his tail.

7.5. (a) The birds is singing.

(b) The birds are singing.

7.6. (a) What are you doing now?

(b) What do you now?

7.7. (a) Yesterday played I with a ball.

(b) Yesterday I played with a ball.

7.8. (a) Want you to go to the movies?

(b) Do you want to go to the movies?

7.9. (a) I am very happy.

(b) I are very happy.

7.10. (a) I take not no for an answer.

(b) I do not take no for an answer.

7.11. (a) The sandwich has been eaten by the girl.

(b) The sandwich has eaten by the girl.

7.12. (a) Yesterday 1 had gone to town.

(b) Yesterday i went to town.

7.13. (a) I can see that you are happy.

(b) I can see that you happy are. 